\title{
Increasing Customers Loyalty MSME of Focused E-Marketing and Quality of Service
}

\author{
Mu'ah $^{1}$, Umar Yeni Suyanto², Kuntoaji Dwi Syaputro ${ }^{3}$, Siti Musarofah ${ }^{4}$, Nurul Qomariah ${ }^{5}$ \\ 1, 2, 3, 4 Institut Tehnologi Dan Bisnis Ahmad Dahlan Lamongan, \\ ${ }^{5}$ Universitas Muhammadiyah Jember
}

Corresponding Author: Nurul Qomariah ${ }^{5}$

Orchid id: 0000-0001-8662-8904

\begin{abstract}
This study aims to examine and analyze the direct effect of Emarketing and service quality on customer loyalty. This research was conducted at the Convection MSME "Arya Project" Babat. The population in this study were all customers recorded for the period September 2019 - January 2020, totaling 100 customers. The number of research samples is 100 customers who are also members of the population. Data analysis used the SPSS for windows application version 24.0. The results showed that the emarketing variable had a positive and significant effect on customer loyalty with the e-marketing regression coefficient of 0.555 with a significance value of $0.000>0.05$. Service quality variables have a positive and significant effect on customer loyalty with a regression coefficient of 0.240 with a significance value of $0.002>0.05$. Overall the results of the research have the implication that e-marketing can help customers interact directly and can expand marketing reach and with good quality customers will always use the product and will not switch to other products.
\end{abstract}

Keywords: e-marketing, customer quality, customer loyalty, convection UMKM.

\section{INTRODUCTION}

In line with the current increase in Indonesia's population, which has reached approximately 268,583,000 people, the need for clothing is also increasing. This increase in population was also matched by increasing the number of textile industries in Indonesia that have been listed on the Indonesia Stock Exchange, the textile and garment sub-sector by 43 companies (Ezez 2019/b/). Data from the Central Statistics Agency (BPS) in mid-2019 noted that the production of the apparel industry grew by $29.19 \%$ on an annual basis. Meanwhile, on a q-t-q basis, this sector grew by $8.79 \%$, the second highest after the furniture industry. According to the records of the Central Statistics Agency (BPS), it turns out that the national textile and textile product (TPT) industry, the apparel industry recorded the largest export value. Throughout 2018, the apparel industry recorded exports worth US \$ 8.62 billion with a growth of $8.9 \%$ y-o-y. On the other hand, exports of the textile industry over the past year were valued at US $\$ 4.651$ billion, down $0.1 \%$ compared to 2017 which was valued at US \$ 4.655 billion. This indicates that the Indonesian convection industry has also increased (Ezez 2019/a/).

The growth of the textile industry will have an impact on the growth of the downstream industry, namely the convection industry to meet people's clothing needs. Increasing the convection industry is because the needs of society are constantly changing with new modes. Community life from time to time is increasingly developing, this is marked by the needs of society that were previously traditional to become modern. The development of this business world has been marked by increasingly fierce competition. No exception in the convection industry. This convection industry must understand new clothing fashions so that it can increase sales turnover, and also can compete with other convection industries. This is due to the increasingly wide open flow of globalization for every business actor. The emergence of very fierce competition causes businesses to compete with each other to be able to face competition and gain a competitive advantage. Because of this, every company is required to be able to create products with the best specifications so that customer desires can be fulfilled. Any industry can survive if it has customers who are loyal to the products offered by the industry. Therefore paying attention to customer desires is the main goal of a business. If the customer's wishes are considered, the customer will feel that their expectations can be fulfilled (Kotler eta Amstrong 2008/). Customers who feel that their desires are taken care of will feel satisfied Satisfaction is the feeling of customers who feel that what is expected exceeds what they receive (Tjiptono 2007/). Customer satisfaction can also be interpreted as feeling happy about the products and services they buy (Buchari 2007/). The feeling of being satisfied with the product and the amount he has felt will make customers do positive things about these products and services (Lupiyoadi 2013/). Positive things that are usually done by satisfied customers are providing positive information about these products and services, recommending these products and services to other customers, inviting the 
public to use these products and services (Qomariah 2016/). In other words, customers who are already satisfied will have a sense of loyalty to the products and services offered.

Customer loyalty is a customer who always makes repeat purchases, which in turn guarantees a stream of income for the company, has a tendency to buy more, is willing to pay a higher price, which will have a direct impact on the profits earned by the company. Another important element of loyalty is the support for a product or service that is manifested in a person's positive experiences and communications. One of the strongest forms of persuasion is someone's speech (Tjiptono eta Candra 2012/). Providing recommendations for a product or service from customers to others is a reflection of the high level of customer loyalty. There are several factors that increase customer loyalty. These factors include e-marketing and the quality of service provided by product and service providers.

The first factor that can increase customers to continue using the products and services that have been used is e-marketing. E-marketing is marketing done through computers (and other electronic goods such as laptops, gadgets) using a means of communication that aims to reduce marketing costs and increase the effectiveness of marketing efforts (Kotler eta Amstrong 2008/). E-marketing is the process of using cyberspace as a communication tool to complement the marketing activities that have been carried out so far. . Electronic marketing or electronic marketing is based on the application of existing marketing principles and techniques through electronic media and more specifically the internet. The terms marketing, internet marketing and online marketing, are often confused and are often seen as synonymous. E-marketing is the process of marketing brands using the internet. It includes the elements of both direct and indirect response marketing and the practice of using a variety of technologies to help connect businesses to customers. Thus e-marketing encompasses all business activities conducting via the worldwide web with the aim of attracting new business, maintaining current business and developing a unique brand. There are many benefits obtained by implementing e-marketing, including: wider prospect reach, there are cost savings, advertisements are delivered more personal, there is an increase in more active interactions.

Several studies on the relationship between e-marketing and customer loyalty have been conducted by several previous researchers. Research (Prasetya eta So 2014/) was conducted at marketing communication companies, the results showed that e-marketing and e-CRM have a positive influence on eloyalty individually and simultaneously. (Supriyanto 2013/) conducted research on Online Soccer Jersey Business, the result is that social media and online marketing systems together have an impact on repeat purchases. (AL-Hawamdeh 2020/) conducted a study on 739 customers who use social media to purchase goods in Jordan, the results of his research show that social media can increase customer loyalty. (Ikhsana, Prisanto, eta Anggraini 2019/) conducted research with the theme of e-marketing communication, brand equity, and viewers loyalty, the results of their research show that emarketing communication and brand equity have a strong effect on the loyalty of viewers on siaranku.com and have a validity level that meets the requirements a study. (Dilham, Sofiyah, eta Muda 2018/) conducted a study with the theme of internet marketing, customer loyalty and brand awareness at female MSMEs in North Sumatra with a sample of 95 respondents and the result was that internet marketing had an impact on customer loyalty. Research (Habib 2019/) was conducted at PT. Bank BNI Syariah Medan Branch Office with the theme of social media marketing, loyalty intentions with the results of the research is that social media marketing variables have an influence on loyalty intentions. Research (Suardana et al. 2017/) found that many foreign tourists returned due to efforts through e-marketing in the tourist areas of Tulamben and Pemuteran. (Prasmara, Rachma, eta Primanto 2019/) conducted research with the theme of online marketing, e-service quality, e-loyalty and e-satisfaction at the Khayrscraf Online Shop, where the results showed that emarketing had no impact on e-loyalty. (Fahrika, Rachma, eta Slamet 2019/) conducted research at Online Shop Joyism Malang with the theme of online marketing research, e-service quality, loyalty, and customer satisfaction with a population of 1253 customers and a sample size of 93 respondents, while the results showed online marketing and e-service quality has a positive impact on customer loyalty. (Fitriana 2019/) conducted research with the theme of e-marketing and e-CRM and customer loyalty at Bank Syariah Mandiri Pontianak Branch with 75 respondents and the results of the research were e-Marketing and e-CRM had a positive effect on ecustomer loyalty.

The next factor that can increase customer loyalty is the quality of service provided by product and service providers. Service quality is a comprehensive assessment made by the customer for the service it receives. Service quality is a customer assessment of the service received. According to (Tjiptono eta Candra 2012/) that quality is considered as a measure of the perfection of a product or service which consists of design quality and conformity quality. Design quality is a specific function of a product or service, conformity quality is a measure of how much the level of conformity between a product or service and the requirements or quality specifications that have been previously set. According to (Parasuraman, Zeithaml, eta Berry 1985/) there are five indicators of service quality that are used as guidelines by customers in assessing service quality, namely: physical form, empathy, reliability, responsiveness, assurance. Providing good service to customers will provide a sense of satisfaction to customers. Satisfied customers will repurchase products and services. Customer loyalty is the tendency of customers to buy a product or use services provided by a company with a high level of consistency. Customer loyalty will be the key to success not only in the short term but in a sustainable competitive advantage. This is because customer loyalty has strategic value for the company. The rewards of loyalty are long term and cumulative. So the longer the loyalty of a customer, the greater the profit the company can get from a customer. Some of the indicators used to measure the customer loyalty variable are: making regular repeat purchases, making purchases outside the product / service line, recommending products / services to other customers (Griffin 2005/). 
Many researchers have conducted several studies that link service quality with customer loyalty. Research of (Qomariah 2008/), (Dewi eta Rulirianto 2011/), (Qomariah 2012/), (Wayan et al. 2013/), (Saputra 2013/), (Hasniaty 2015/), ., (Djanas 2016/), (Mulyawan eta Rinawati 2016/), (Maskur, Qomariah, eta Nursaidah 2016/) (Iriyanti, Qomariah, eta Suharto 2016/), (Verriana eta Anshori 2017/), (Sutrisno, Cahyono, eta Qomariah 2017/), (Muzammil, Yunus, eta Darsono 2017/), (Qomariah 2018/), (Sofiati, Qomariah, eta Hermawan 2018/), , (Mutmainnah 2018/), (Indarto et al. 2018/), (Ratnasari eta Gumanti 2019/), (Nursaid, Purnomo, eta Qomariah 2020/), (Lie et al. 2019/), (Subagja eta Susanto 2019/), (Soliha et al. 2019/), (Juanamasta et al. 2019/), (Muharmi eta Sari 2019/), (Surjaatmadja, Hubaib, eta Muda 2019/), (Purwati eta Hamzah 2019/), Qomariah et al., 2020), (Qomariah et al. 2020/), (Mendoza et al. 2020/) conduct research that links service quality with customer loyalty.

Babat District, Lamongan Regency is the center of the convection industry, one of which is serving orders for $t-$ shirts. The T-shirt and screen printing industry in Tritunggal Village embraces at least 143 home industries and is divided into three clusters. The clusters are divided based on the number of workers in the industry. The large cluster has a capacity of 20-30 workers, the medium cluster is $10-15$ people, while the small cluster only has 5-10 people (http://nourelhay.blogspot.com/2013/11/desa-tritunggal-kecbabat-kab -llamongan.html). Arya Convection Babat Project, is an UMKM that is engaged in the convection business which also takes part in advancing the convection industry in Babat District, Lamongan Regency. With so many convection industries, competition in getting customers is also getting tighter. In order for customers to continue using the convection services from the UMKM Arya Convection Project, the leadership is required to continue to make various new breakthroughs such as the use of sophisticated and modern tools such as (digital printing, high speed sewing machines), formulating a vision and mission, and commitment. Therefore, the purpose of this study is to determine and analyze the effect of e-marketing and service quality on customer loyalty at the MSME Arya Convection Project. From the theory and previous research that has been described, the research hypotheses built in this study are:

H1: E-Marketing Has An Impact On Customer Loyalty

H2: Service Quality Affects Customer Loyalty.

\section{RESEARCH METHODS}

This type of research used in this research is quantitative research. Population is a generalization area consisting of objects or subjects that have certain qualities and characteristics that are determined by researchers to study and then draw conclusions (Sugiyono 2013/). The population in this study were 100 customers of the UMKM Arya Project Convection. For 5 months (September 2019 - January 2020). The sample is part of the number and characteristics of the population. The sample in this study were customers of the Arya Project Convection for 5 months with a total of 100 customers. The sampling technique used in this study was total sampling. Total sampling is a sampling technique equal to the population (Ghozali 2011/). Validity and reliability tests were conducted to test the measuring instrument in the form of a questionnaire. Multiple linear regression analysis is used to determine the effect of independent variables (e-marketing and service quality) on the dependent variable (customer loyalty). Partial significance test and simultaneously used ttest and F-test.

\section{RESULTS AND DISCUSSION}

\section{Descriptive Statistical Analysis Results}

Based on the descriptions of respondents on the basis of gender, the results showed that the majority of customers who became respondents were male 83 people $(83 \%)$ and 17 women (17\%). Based on the description of respondents on the basis of age, it can be seen that the majority of respondents at the company are <30 years old, namely as many as 53 people (53\%). Second, respondents aged 30-40 years, as many as 19 people $(19 \%)$. Finally, there were 28 respondents aged $>40$ years $(28 \%)$.

\section{Results of Validity and Reliability Tests}

The results of statistical calculations for the validity test are in table 1, which shows that the r-count value for all research variable indicators shows a number greater than the r-count value. Thus it can be concluded that all statements put forward in the questionnaire as a measuring tool are not valid. The results of the reliability test for the research variables are in table 2, which shows that the Cronbach alpha value for all variables has a value above 0.60 , so it can be concluded that all lists of statements are reliable.

Table 1. Test Results of the Validity of Research Variables

\begin{tabular}{|c|c|c|c|c|}
\hline Variable & Statement & r-Count & r- Table & Information \\
\hline \multirow{5}{*}{$\begin{array}{l}\text { E-Marketing } \\
\text { (X1) }\end{array}$} & $\mathrm{X} 1.1$ & 0.834 & 0.1966 & Valid \\
\hline & $\mathrm{X} 1.2$ & 0.900 & 0.1966 & Valid \\
\hline & $\mathrm{X} 1.3$ & 0.883 & 0.1966 & Valid \\
\hline & $\mathrm{X} 1.4$ & 0.722 & 0.1966 & Valid \\
\hline & $\mathrm{X} 1.5$ & 0.770 & 0.1966 & Valid \\
\hline \multirow{5}{*}{$\begin{array}{c}\text { Service } \\
\text { Quality } \\
\text { (X2) }\end{array}$} & $\mathrm{X} 2.1$ & 0.824 & 0.1966 & Valid \\
\hline & $\mathrm{X} 2.2$ & 0.682 & 0.1966 & Valid \\
\hline & $\mathrm{X} 2.3$ & 0.806 & 0.1966 & Valid \\
\hline & X2.4 & 0.805 & 0.1966 & Valid \\
\hline & $X 2.5$ & 0.494 & 0.1966 & Valid \\
\hline \multirow{4}{*}{$\begin{array}{l}\text { Customer } \\
\text { Loyality } \\
\text { (Y) }\end{array}$} & Y1 & 0.620 & 0.1966 & Valid \\
\hline & $\mathrm{Y} 2$ & 0.743 & 0.1966 & Valid \\
\hline & Y3 & 0.905 & 0.1966 & Valid \\
\hline & Y4 & 0.862 & 0.1966 & Valid \\
\hline
\end{tabular}


International Journal of Engineering Research and Technology. ISSN 0974-3154, Volume 13, Number 10 (2020), pp. 2729-2735

(C) International Research Publication House. https://dx.doi.org/10.37624/IJERT/13.10.2020.2729-2735

Table 2. Research Variable Reliability Test Results

\begin{tabular}{|c|c|c|}
\hline Variable & Alpha Value & Information \\
\hline E-Marketing $(\mathrm{X} 1)$ & 0.810 & Reliabel \\
\hline Service Quality $(\mathrm{X} 2)$ & 0.786 & Reliable \\
\hline Customer Loyality (Y) & 0.811 & Reliable \\
\hline
\end{tabular}

\section{Hypothesis Testing Results and Determination Coefficient}

Multiple linear regression analysis is used to determine the effect of independent variables on the dependent variable (Arikunto, 2006). The independent variables in this study are: e-marketing and service quality, while the dependent variable is: customer loyalty. The results of the multiple linear regression analysis are presented in Table 3, where the regression coefficient value for the e-marketing variable is 0.555 and the coefficient value for the service quality variable is 0.240 . The constant value is -0.538 . The significance value for the e-marketing variable is 0.000 and the significance value for the service quality variable is 0.000 . Thus the equation that can be compiled from the results of these statistics is: $\mathrm{Y}=0.538+0.555 . \mathrm{X} 1+0.240 . \mathrm{X} 2+\mathrm{e}$. From the results of this analysis, it can be concluded that the first hypothesis which states that e-marketing has an effect on customer loyalty is accepted. Meanwhile, the second hypothesis which says that service quality affects customer loyalty is also accepted.

The results of the coefficient of determination are shown in Table 4 which shows that the value of the coefficient of determination shown by the $\mathrm{R}$ Square number is 0.722 which comes from $(0.722 \times 0.722)$. In table 4.because there are two variables, using the $\mathrm{R}$ square means that $72.2 \%$ of the variance of customer loyalty can be explained by the variance of e-marketing and service quality, while the remaining $27.8 \%$ is explained by other variables not listed in this study. like trust and brand.

Table 3. Results of Multiple Linear Regression Analysis

\begin{tabular}{|c|c|c|c|c|c|}
\hline Information & $\mathbf{B}$ & $\begin{array}{c}\text { Std. } \\
\text { Error }\end{array}$ & Beta & $\mathbf{T}$ & Sig. \\
\hline (Constant) & -.538 & 1.109 & & -.485 & .629 \\
\hline E-Marketing (X1) & .555 & .052 & .672 & 10.589 & .000 \\
\hline $\begin{array}{c}\text { Service Quality } \\
\text { (X2) }\end{array}$ & .240 & .056 & .271 & 4.272 & .000 \\
\hline
\end{tabular}

Table 4. Results of the Analysis of the Coefficient of Determination

\begin{tabular}{|c|c|c|c|c|}
\hline Model & R & R Square & $\begin{array}{c}\text { Adjusted } \\
\text { R Square }\end{array}$ & $\begin{array}{c}\text { Std. Error } \\
\text { of the } \\
\text { Estimate }\end{array}$ \\
\hline 1 & $.850^{\mathrm{a}}$ & .722 & .716 & 1.320 \\
\hline
\end{tabular}

\section{DISCUSSION}

\section{The Effect of E-Marketing on Customer Loyalty}

The results of multiple linear regression analysis show that the coefficient value of the e-marketing variable is 0.555 with a tcount value of 10.589 which is greater than the $t$-count value. The significance value of the e-marketing variable appears to be 0,000 which is smaller than the required significance value of 0.005 . From the results of this calculation, the hypothesis which states that the e-marketing variable has a positive and significant effect on customer loyalty is "accepted". Emarketing is an effort made by companies so that the wider community can get to know their products through the internet and other tools (Tjiptono eta Candra 2012/). Currently every company is required to be able to market its products through e-marketing because of the information and technology era. Companies that do not take advantage of e-marketing may not be recognized by the public. Information about marketed products can be accessed through online marketing media, so that the public will easily know the latest information about the product being offered. This new information will provide its own satisfaction for the product / service user community so that there will be a desire to use the product / service again. Research that also examines the problem of e-marketing with customer loyalty includes: (Supriyanto, 2013), (Prasetya \& So, 2014), (Suardana et al., 2017), (Dilham et al., 2018), (Fahrika et al., 2019), (Fitriana, 2019), (Prasmara et al., 2019), (Habib, 2019), (Ikhsana et al., 2019), (AL-Hawamdeh, 2020).

\section{The Effect of Quality Services on Customer Loyalty}

The second hypothesis states that service quality variables have a positive effect on customer loyalty. Based on the results of hypothesis testing in table 4 , it can be seen that the coefficient value of $\mathrm{b} 2$ is 0.240 with a significance value of $0.002<0.05$, which means that there is a positive and significant influence on customer quality variables on customer loyalty. The test results are in line with the hypothesis that has been made where there is a positive and significant effect of service quality on customer loyalty. The tcount value is 4.272 while the t-table value is 1.984 . If $\mathrm{t}$ count> t-table, the significance value is less than $5 \%$ and the second hypothesis is accepted. The better the quality of service provided by the company to customers, the greater the customer loyalty. Service quality is a customer assessment of the service received (Tjiptono \& Candra, 2012). The services provided can be in the form of goods or services. Customers who get products and services that match their expectations, the customers will feel satisfied. Customers who are satisfied will make repeat purchases and will also recommend these products and services to other customers. Research that links service quality with customer loyalty includes: (Qomariah 2008/), (Dewi eta Rulirianto 2011/), (Qomariah 2012/), (Wayan et al. 2013/), (Saputra 2013/), (Hasniaty 2015/), ., (Djanas 2016/), (Mulyawan eta Rinawati 2016/), (Maskur, Qomariah, eta Nursaidah 2016/) (Iriyanti, Qomariah, eta Suharto 2016/), (Verriana eta Anshori 2017/), (Sutrisno, Cahyono, eta Qomariah 2017/), (Muzammil, Yunus, eta Darsono 2017/), (Qomariah 2018/), (Sofiati, Qomariah, eta Hermawan 2018/), , (Mutmainnah 2018/), (Indarto et al. 
2018/), (Ratnasari eta Gumanti 2019/), (Nursaid, Purnomo, eta Qomariah 2020/), (Lie et al. 2019/), (Subagja eta Susanto 2019/), (Soliha et al. 2019/), (Juanamasta et al. 2019/), (Muharmi eta Sari 2019/), (Surjaatmadja, Hubaib, eta Muda 2019/), (Purwati eta Hamzah 2019/), Qomariah et al., 2020), (Qomariah et al. 2020/), (Mendoza et al. 2020/).

\section{CONCLUSIONS AND RECOMMENDATIONS}

\section{Conclusion}

The results showed that e-marketing had a positive and significant effect on customer loyalty of the Babat Convection Arya Project. Service quality variable has a positive and significant effect on customer loyalty in the Arya Convection Babat Project.

\section{Suggestion}

Suggestions that can be conveyed to the parties in this study are: company owners need to pay attention to e-markting and service quality. The owner of this convection UMKM Arya Project must take advantage of current technology. With the existence of e-marketing, it is hoped that it can assist in informing and interacting directly with customers, expanding the reach of online marketing. With good quality service to customers, customers will always use these products and will not turn to other products. Research is expected to be able to carry out continuous research in order to see and assess any changes in respondent behavior from time to time.

\section{REFERENCES}

[1] AL-Hawamdeh, Majd Mohammad. 2020/. «The Impact Of Social Media On Sales». INTERNATIONAL JOURNAL OF SCIENTIFIC \& TECHNOLOGY RESEARCH 9(02):4431-37.

[2] Buchari, Alma. 2007/. Manajemen Pemasaran dan Pemasaran Jasa, Edisi Revisi. Bandung: Alfabeta.

[3] Dewi, Shinthya Anisa, eta Rulirianto. 2011/. «PENGARUH CITRA PERUSAHAAN, KEPERCAYAAN PELANGGAN, DAN KUALITAS PELAYANAN TERHADAP LOYALITAS PELANGGAN PT BUANA LANGGENG JAYA TULUNGAGUNG Shinthya». J A B Jurnal Aplikasi Bisnis 244-49.

[4] Dilham, Ami, Fivi Rahmatus Sofiyah, eta Iskandar Muda. 2018/. «The internet marketing effect on the customer loyalty level with brand awareness as intervening variables». International Journal of Civil Engineering and Technology 9(9):681-95.

[5] Djanas, Asmiati. 2016/. «Kualitas Pelayanan dan Citra Perusahaan terhadap Kepuasan Serta dampaknya terhadap Loyalitas Wisatawan». JSM (Jurnal Sains Manajemen) Program V(2):184-92.

[6] Ezez. 2019/a/. «(https://kemenperin.go.id/artikel/20641/Industri-PakaiJadi-Catatkan-Pertumbuh-Paling-Tinggi).»

[7] Ezez.

2019/b/. «(https://www.sahamok.com/emiten/sektor-anekaindustri/sub-sektor-tekstil-garment/).»

[8] Fahrika, Afifa, N. Rachma, eta Afi Rachmat Slamet. 2019/. «Pengaruh Online Marketing Dan E-Service Quality Terhadap Loyalitas Dengan Kepuasan Sebagai Variabel Intervening Pada Online Shop Joyism Malang». Jurnal Ilmiah Riset Manajemen 8(4):52-63.

[9] Fitriana, Ana. 2019/. «Pengaruh E-Marketing dan ECRM terhadap Loyalitas Nasabah Menggunakan Internet Banking Bank Syariah Mandiri». Creative Information Technology Journal 4(4):306.

[10] Ghozali, Imam. 2011/. Aplikasi Analsiis Multivariate dengan Program SPSS. Semarang: BP Universitas Diponegoro.

[11] Griffin, Jill. 2005/. Customer Loyalty:Menumbuhkan dan Mempertahankan. Kesetiaan Pelanggan,. Jakarta: Erlangga.

[12] Habib, Jun. 2019/. Pengaruh Social Media Marketing Terhadap Loyality Intentions Pada Pt . Bank Bni Syariah Kantor Cabang Medan. Medan.

[13] Hasniaty, Hasniaty. 2015/. «Customer Perception On Products Pricing Service Quality Towards Customers Quality Relationships And Loyalty Of Domestic Airlines Indonesia». International Journal of Scientific \& Technology Research 4(8):181-88.

[14] Ikhsana, Putri Dewi, Guntur Freddy Prisanto, eta Rosita Anggraini. 2019/. «Penerapan Strategi E-Marketing Communication Dan Ekuitas Merek Siaranku.Com Terhadap Loyalitas Viewers». Inter Komunika: Jurnal Komunikasi 4(1):58.

[15] Indarto, Erik Wahyu, Imam Suroso, Sudaryanto Sudaryanto, eta Nurul Qomariah. 2018/. «the Effect of Brand Image and Product Attributes on Customer Satisfaction and Customer Loyalty». Jurnal Aplikasi Manajemen 16(3):457-66.

[16] Iriyanti, Emik, Nurul Qomariah, eta Akhmad Suharto. 2016/. «PENGARUH HARGA, KUALITAS PRODUK DAN LOKASI TERHADAP LOYALITAS PELANGGAN MELALUI KEPUASAN SEBAGAI VARIABEL INTERVENING PADA DEPOT MIE PANGSIT JEMBER». Jurnal Manajemen Dan Bisnis Indonesia 2(1).

[17] Juanamasta, I. Gede, Ni Made Nopita Wati, Erna Hendrawati, Wiwin Wahyuni, Mira Pramudianti, Nugrahini Susantinah Wisnujati, Anindya Prastiwi Setiawati, Susetyorini Susetyorini, Umi Elan, Rusdiyanto Rusdiyanto, Denny Astanto, Bustanul Ulum, Susan Novitasari Khadijah, Adrianto Trimarjono, Mochamad Syafii, Abdullah Mubarroq, Kristiningsih Kristiningsih, Rita Dwi Pratiwi, Veri Veri, Lusy Tunik Muharlisiani, eta M. Chairul Basrun Umanailo. 2019/. «The role of customer service through customer relationship management $(\mathrm{Crm})$ to increase customer loyalty and good image». International Journal of Scientific and Technology Research 8(10):2004-7.

[18] Kotler, Philip, eta Gary Amstrong. 2008/. PrinsipPrinsip Pemasaran. Jakarta: Penerbit Erlangga. 
[19] Lie, Darwin, Acai Sudirman, E. Efendi, eta Marisi Butarbutar. 2019/. "Analysis of mediation effect of consumer satisfaction on the effect of service quality, price and consumer trust on consumer loyalty». International Journal of Scientific and Technology Research 8(8):421-28.

[20] Lupiyoadi, Rambat. 2013/. Manajemen Pemasaran. Jakarta: Salemba Empat.

[21] Maskur, Muhammad, Nurul Qomariah, eta Nursaidah. 2016/. «Analisis Pengaruh Kualitas Pelayanan, Harga, Dan Kepuasan Pelanggan Terhadap Loyalitas Pelanggan (Studi Kasus pada Bengkel Mobil Larasati Lumajang)». Jurnal Sains Manajemen \& Bisnis Indonesia VI(2):21221.

[22] Mendoza, Irma Milagros Carhuancho, Oscar Jhonny Bravo Chávez, Fernando Alexis Nolazco Labajos, Carlos Oswaldo Venturo Orbegoso, eta Heder Quispe Quiñonez. 2020/. «Determinants of loyalty in a private university». International Journal of Scientific and Technology Research 9(2):4549-54.

[23] Muharmi, Habibah, eta Kurnia Sari. 2019/. «Pengaruh Service Quality, Food Quality, Dan Perceived Value Terhadap Consumer Satisfaction Dan Behavioral Intentions». Jurnal Manajemen Dan Bisnis Indonesia 5(2):193-203.

[24] Mulyawan, Ali, eta Rinawati. 2016/. «Pengaruh Kualitas Layanan Akademik Terhadap Kepuasan Mahasiswa Serta Implikainya Pada Loyalitas Mahasiswa». Jurnal Ekonomi, Bisnis \& Entrepreneurship 10(2):119-31.

[25] Mutmainnah, Mutmainnah. 2018/. «Pengaruh Kualitas Layanan Dan Citra Perusahaan Terhadap Kepuasan Dan Loyalitas Nasabah». Jurnal Manajemen dan Pemasaran Jasa 10(2):201.

[26] Muzammil, Abdul, Mukhlis Yunus, eta Nurdasila Darsono. 2017/. «Pengaruh Kualitas Pelayanan Dan Citra Perusahaan Terhadap Loyalitas Pelanggan Indihome Pt. Telkom Indonesia Di Banda Aceh Dengan Kepuasan Dan Kepercayaan Pelanggan Sebagai Variabel Mediasi». Jurnal Manajemen dan Inovasi 8(3):104-33.

[27] Nursaid, Sapta Hadi Purnomo, eta Nurul Qomariah. 2020/. «The Impact of Service Quality and Institutional Image on the Satisfaction and Loyalty of Master of Management Students». Or. 156-61 in 1st Borobudur International Symposium on Humanities, Economics and Social Sciences (BIS-HESS 2019). Libk. 436. Magelang.

[28] Parasuraman, A., VA Zeithaml, eta LL Berry. 1985/. «A conceptual model of service quality and its implications for future research». Journal of Marketing 49(Fall 1985):41-50.

[29] Prasetya, Filo Novandi, eta Idris Gautama So. 2014/. «Pengaruh E-Marketing dan E-Crm Terhadap E-Loyalty Website Usaha Komunikasi Pemasaran». Binus Business Review 5(1):8.

[30] Prasmara, Ariska Estu, N. Rachma, eta Alfian Budi Primanto. 2019/. «Prodi manajemen». e - Jurnal Riset Manajemen 29-44.
[31] Purwati, Astri Ayu, eta Muhammad Luthfi Hamzah. 2019/. «Total service quality management and it's impact on customer satisfaction and loyalty of online transportation in Indonesia». International Journal of Scientific and Technology Research 8(11):1066-70.

[32] Qomariah, Nurul. 2008/. «Pengaruh kualitas pelayanan terhadap keputusan dan loyalitas pelanggan:(Studi kasus pada Universitas Muhamadiyah Jember)». Universitas Jember.

[33] Qomariah, Nurul. 2012/. «Pengaruh Kualitas Layanan dan Citra Institusi Terhadap Kepuasan dan Loyalitas Pelanggan». Jurnal Aplikasi Manajemen 10(1):177-87.

[34] Qomariah, Nurul. 2016/. Marketing Adactive Strategy. Jember: Cahaya Ilmu.

[35] Qomariah, Nurul. 2018/. «Impact of Customer Value, Brand Image and Product Attributes to Satisfaction and Loyalty Tourism Visitors in Jember Regency». Mediterranean Journal of Social Sciences 8(5-1):12935 .

[36] Qomariah, Nurul, Anie Budiastuti, Abadi Sanosra, Arik Susbiani, eta Eko Budisatoto. 2020/. «Building Student Satisfaction and Loyalty Based on Service Quality and Institutional Image». 7(9):24-33.

[37] Ratnasari, Dwi, eta Tatang Ary Gumanti. 2019/. «Relationship marketing, service quality, satisfaction and customers loyalty of bank sharia mandiri banyuwangi». International Journal of Scientific and Technology Research 8(6):7-10.

[38] Saputra, Falla Ilhami. 2013/. «Kualitas Layanan , Citra dan Pengaruhnya terhadap Loyalitas melalui Kepuasan Pelanggan ( Studi Pada PT Bank Bni 46 Sentra Kredit Kecil Surabaya )». Aplikasi Manajemen 11(3):445-57.

[39] Sofiati, Iis, Nurul Qomariah, eta Haris Hermawan. 2018/. «DAMPAK KUALITAS PELAYANAN TERHADAP LOYALITAS KONSUMEN». Jurnal Sains Manajemen \& Bisnis Indonesia 8(2):244-59.

[40] Soliha, Euis, Alimuddin Rizal, Ali Maskur, Nursalinda Bela Mawarni, eta Rochmani Rochmani. 2019/. «Service quality, bank image, and customer loyalty: The mediating role of customer satisfaction». International Journal of Scientific and Technology Research 8(10):2667-71.

[41] Suardana, I. W., N. M. Ariani, N. G. A. S. Dewi, eta I. W. Darsana. 2017/. «PENERAPAN E-MARKETING DALAM PENINGKATAN KUNJUNGAN DAN LOYALITAS WISATAWAN DI KAWASAN TULAMBEN». Buletin Udayana Mengabdi 16(September):72-77.

[42] Subagja, Iwan Kurniawan, eta Putri Herlanies Susanto. 2019/. «Pengaruh Kualitas Pelayanan, Kepuasan Nasabah Dan Citra Perusahaan Terhadap Loyalitas Nasabah Pt. Bank Central Asia Tbk Kantor Cabang Pondok Gede Plaza». Jurnal Manajemen Bisnis Krisnadwipayana 7(1):69-84.

[43] Sugiyono. 2013/. Metode Penelitian Pendidikan Pendekatan Kuantitatif, Kualitatif, dan R\&D. Bandung: Alfabeta. 
[44] Supriyanto, Ari. 2013/. ANALISIS PENGGUNAAN TEKNOLOGI INTERNET ( SOSIAL MEDIA ) DALAM SISTEM PEMASARAN ONLINE UNTUK MENINGKATKAN KEPUASAN DAN PEMBELIAN BERULANG PADA BISNIS JERSEY BOLA ONLINE ARTIKEL PUBLIKASI ILMIAH Diajukan Untuk Memenuhi Tugas Dan Syarat-Syarat Guna Memperole.

[45] Surjaatmadja, Surachman, Ahmad Hubaib, eta Iskandar Muda. 2019/. «The effect of brand image, service quality and price towards the decision of the use of remittance (The remittance from the indonesian migrant workers in hongkong to Indonesia through the stateowned banks)». International Journal of Scientific and Technology Research 8(8):214-21.

[46] Sutrisno, Dwi Cahyono, eta Nurul Qomariah. 2017/. «ANALISIS KUALITAS PELAYANAN, KEPERCAYAAN SERTA CITRA KOPERASI TERHADAP KEPUASAN DAN LOYALITAS ANGGOTA». Jurnal Sains Manajemen \& Bisnis Indonesia 7(2):157-74.

[47] Tjiptono, Fandy. 2007/. Service, Quality \& Satisfaction. Yogyakarta: Andi.

[48] Tjiptono, Fandy, eta Gregorius Candra. 2012/. Pemasaran Strategik. Yogyakarta: Andi.

[49] Verriana, Rusdyana Intan, eta Mohamad Yusak Anshori. 2017/. «Pengaruh Kualitas Layanan ( Service Quality ) Terhadap Loyalitas Melalui Kepuasan». Accounting and Managemen Journal 1(1):63-79.

[50] Wayan, Ni, Karthi Sutharjana, Armanu Thoyib, Eka Afnan Taroena, eta Mintarti Rahayu. 2013/. «Organizational Citizenship Behavior Effect On Patient Satisfaction And Loyalty Through Service Quality (Study On Maternity Hospitals In Indonesia)». International Journal of Scientific \& Technology Research 2(5):288-99. 